FILOZOFIA

Roč. 75, 2020, č. 2

DOI: https://doi.org/10.31577/filozofia.2020.75.2.5

\title{
HAMANN A HERDER O METAKRITICE. PŘÍSPĚVEK K DĚJINÁM POJMŮ
}

BŘETISLAV HORYNA, Filozofický ústav Slovenskej akadémie vied, Bratislava, SR

HORYNA, B.: Hamann and Herder on Metacriticism. Contribution to the History of Concepts

FILOZOFIA, 75, 2020, No 2, pp. $133-147$

\begin{abstract}
The paper Hamann and Herder on Metacriticism. A Contribution to the History of Concepts deals with a general context of the origin and extension of the neologism "metacriticism". The history of this term begins in 1784 when German writer and philosopher J. G. Hamann used it to name his conception of Immanuel Kant's Critic of Pure Reason. However, Hamann provided only a brief framework of the conception of metacriticism. The task to elaborate the whole theory was undertaken by J. G. Herder, who published two-volume work Verstand und Erfahrung. Eine Metakritik zur Kritik der reinen Vernunft in 1799. Here begun a long-term conflict in German philosophy about the conception of metacriticism, about Herder's controversial criticism of Kant and generally about the task of critical philosophy. Modern research shows that there are series of impulses in Hamann's and Herder's theory of metacriticism which influenced the development of German idealism philosophy. Attached to this paper is the translation of Hamann's very first text in which the term metacriticism occurred.
\end{abstract}

Keywords: History of concepts - Transcendental idealism - Criticism and metacriticism - Hamann - Herder - Kant - Reason - Purism of reason Philosophy of language

\section{Úvod}

Tradice kritického myšlení vyvrcholila ve 20. století ve formulaci první povinnosti moderní filosofie, kterou uvedli Horkheimer a Adorno v práci Dialektika osvícenství (Horkheimer - Adorno 1969). Úkol filosofie spočíval nejen $\mathrm{v}$ jejich očích $\mathrm{v}$ tom, že zbaví moci dogmatické ideologie a nahradí světový názor (postoj vznikající nekritickým akceptováním kolektivních patologií sekulárního či religiózního druhu) sebe sama zpytujícím, sebekritickým a sebe-osvíceným rozumem (Habermas 1983, 418). ${ }^{1}$ Tím se ustavilo základní metodické stanovisko: filosofie, má-li jaká být, musí být kri-

\footnotetext{
${ }^{1}$ Termín „sebe-osvícený rozum“ použil v poznámkách k Dialektice osvícenství J. Habermas (1983, 418).
} 
tická ve vztahu ke svým předpokladům, premisám, argumentům, důkazům, formulovaným poznatkům a př́íp. soudům o dějinných tendencích. Kritická filosofie není bezhlavě odmítajícím, rozbíjejícím a ničícím kladivem, nýbrž zůstává specifickým způsobem přijímání světa s tím rozdílem, že minimalizuje úlohu přesvědčení, názoru, víry, autority, tlaku tradice nebo předsudečných hledisek a opírá se o rozumovou schopnost sebeanalýzy možností sebelimitujícího rozumového poznání.

Svým způsobem (nejen intuitivně, ale často s plným uvědoměním účelu a potenciálu analogických konceptů filosofie) se tak projevilo kladení filosofie jako otázky a otázek filosofie po možné míře zatížení rozumu při poznávací konceptualizaci světa. Tato linie probíhá vedle klasických monistických logicko-metafyzických systémů a její hlavní znak, společný jejím nejrůzněji diverzifikovaným historickým podobám, se nachází ve skepsi. Skeptická filosofie je nezbytně také filosofíi skepse (Horyna 2006), tzn. objektem jejího kritického uchopování je prvořadě skepse samotná. Tradice pyrrhónské skepse znala a dodnes uplatňuje techniku vystavení skepse skepsi; novopyrrhónská skepse je v okamžiku svého působení vždy již meta-skepsí. ${ }^{2}$

Během krátké éry německého idealismu, která splývá s údobím rozkvětu německé romantiky, získal projekt kritiky a osoby kritika jakožto svébytného myslitele epochální význam. Zakladatelé rané romantiky bratři Schlegelové postavili na kritice její systémovou teorii a z ní odvodili metodické požadavky na (německou) literaturu, básnictví, filosofii a vědu. V časopise Athenäum, ${ }^{3}$ jenž založili, vydávali a většinově do něj přispívali, se odrážejí všechny původní kritické motivy raně romantické estetiky, př́rodní filosofie a poetologie, mezi nimiž vystupují do popředí podněty přejímané z „pozdního“ díla J. G. Herdera. ${ }^{4}$

\section{Pruský Hume, metakritikus Hamann a hermetik Herder}

Poslední dvě desetiletí 18. století a přelom do 19. století jsou v dějinách německého myšlení mimořádně plodným a živým obdobím. Poté, co I. Kant vydal Kritiku čistého rozumu, začala namnoze ostrá a prudká polemika, do níž se zapojily velké části německých vzdělaneckých kruhů. Sledování dobových svárů je dodnes strhující: tehdy jako dnes spojovala kontrahenty všech debat společná starost o rozum, a co víc čekat od filosofie než péči o lidskou racionalitu zvláště v dobách, kdy je její pojetí vystaveno takovým změnám jako během osvícenství, v díle I. Kanta, v pokusech některých jeho současníků o vlastní systémovou cestu k osahání rozumových možností a v kritickém vstřebávání nové síly rozumu, jíž se mnozí obávali, aniž by pochopili. Zásadní

${ }^{2}$ K novopyrrhónské skepsi viz Horyna 2006, kap. VI. Novopyrrhónská skepse ve 20. století Odo Marquard.

${ }^{3}$ Athenäum (též Athenaeum) byl hlavní tiskový orgán rané romantiky. Bližší viz Horyna (2005).

${ }^{4}$ J. G. Herder $(1744$ - 1803) se nedožil ani šedesáti let; rozlišovat dílo „raného“ a „pozdního“ Herdera považuji proto za nevhodné. 
vliv měly tyto intelektuální půtky na umění výkladu filosofických a literárně-filosofických textů, systematické reflexe a na ní postavené recepce diskutovaných děl, objasnění pozic v dobovém kontextu německé filosofie, pochopení vlivu jednotlivých osobností na vznik a podobu německého idealismu a především objasnění jejich role v teoretickém hnutí, jež se dnes označuje výrazem německá klasická filosofie.

Sem spadá rovněž dobově hojně komentovaný a zakrátko téměř úplně zapomenutý střet mezi I. Kantem, jeho královeckým studentem J. G. Herderem a Kantovým kolegou a „spolubojovníkem za pravdu“ (Schlegel 1813, 33) J. G. Hamannem, jedním z nejoriginálnějších spisovatelů $\mathrm{v}$ německé literárně-filosofické kultuře 18 . století. Jejich spor začal víceméně nechtěně J. G. Hamann, první čtenář Kantovy Kritiky čistého rozumu (dále jako $K \check{C} R$ ), ${ }^{5}$ dopisem J. G. Herderovi z 15. září 1784, do kterého zahrnul krátkou, ale výbušně koncipovanou noticku, dnes známou pod názvem Metakritika purismu rozumu (Hamann 1784). Ještě v témže listě charakterizoval svůj nárys kritiky I. Kanta jako „směšnou myš“, jež porodila horu, přesto se zhruba po celý následující rok objevují v jeho nejdůvěrnější korespondenci zejména s Jacobim poznámky svědčící o úmyslu Metakritiku rozvést podrobněji. Poté, co začal Kant pracovat na druhém vydání $K \check{C} R$, Hamann od svého záměru upustil a soustředil se na kolegiální ovlivňování Kanta, jehož chtěl přimět k opuštění strohého formalismu čistého rozumu, $\mathrm{k}$ převzetí jeho, tj. Hamannových základních tezí o vztahu myšlení a řeči a také $\mathrm{k}$ volbě jiného stylu vyjadřování, než byl př́liš vznešený a nemístný „cant-style“ používaný i tam, kde by stačila, volně přeloženo, jen mluva galérky. ${ }^{6}$ Hamann věřil, že se mu jeho záměr podaří i pro přátelství, které k sobě oba chovali a pro úctu, kterou dal několikrát najevo vůči ,pruskému Humovi“", jak př́ležitostně Kanta nazýval. ${ }^{7}$ Důvod k sebedůvěře mu dával fakt, že již jednou prriměl Kanta k vyrovnání se s problémy, které do filosofie vnesl Hume, Hamannem obdivovaný Kantův „buditel“ (Brose 2006). Posléze ale zjistil, že ve svých úmyslech selhal a nepřiměje Kanta ani k tomu nejzákladnějšímu, aby v $K C \check{C} R$ vůbec začal reflektovat vztah rozumu a řeči. Na korekturu už mu nezbýval čas. V roce 1788 Hamann zemřel a z celé snahy o ovlivnění vưči Hamannovi stejně jako

\footnotetext{
${ }^{5}$ Hamann četl pro Kanta korektury jeho první Kritiky. Tato vzájemná pomoc byla obvyklá i mezi autory, kteří spolu nemuseli souhlasit, ale dokázali se v př́slušném textu odborně orientovat. Korektury Herderova spisu o metakritice tak četl Jean Paul.

${ }^{6}$ V dopise Ch. J. Krausovi ze dne 13. 12. 1784, kde si stěžuje, že ,er (rozuměj Kant), in einem cantstyle schreibe, was man mit ,Gaunersprache“ oder ,Kauderwelsch“ wiedergeben könnte“ (,,píše cantovským stylem i to, co by se dalo napsat řečí gaunerů nebo hantýrkou“").

${ }^{7}$ První doložené setkání obou mužů se datuje rokem 1759 a týkalo se kuriózního Kantova nápadu: nabídl Hamannovi, že spolu napíšou populární učebnici fyziky pro děti, do níž Kant dodá matérii a Hamann obstará „kindliche Form“. Není jasné, nakolik to Kant myslel vážně a nakolik chtěl Hamanna vytrhnout z náboženského blouznění, do kterého upadl v Londýně.
} 
Humovi dokonale imunizovaného Kanta zůstalo sotva pár povzdechů nad Kantovou tvrdošíjností. ${ }^{8}$

Z Metakritiky rozumového purismu zbyl fragment v Herderově složce s dopisy, mezi nimiž byl ještě jeden dřívější, který tento Hamannův neologismus obsahuje doloženě poprvé. ${ }^{9}$ Hamann začal po smrti získávat pověst, jejíž základní znaky přetrvávají dodnes; antiosvícenec, protože kritizoval zbožšt'ování rozumu; předchůdce hnutí Sturm und Drang, protože vystupoval (zejména literárně) značně nonkonformně; jako předchůdce filosofie jazyka, protože chtěl postavit epistemologii nejen na průzkumu rozumových mohutností, ale také na zkoumání utvárejícího vlivu řeči; jako předchůdce teorie jazykového relativismu či dokonce přímo Sapir-Whorfovy hypotézy, protože napsal ve fragmentu Metakritiky, že „,elá schopnost myslet spočívá na řeči ${ }^{10}$; jako zakladatel německého iracionalismu (Berlin 1995), protože někteří si nedokázali vzít $\mathrm{z}$ jeho nesmírně komplikovaných textů nic racionálního a nazvali ho Mágem Severu. ${ }^{11}$ Již následující generaci se podařilo Hamanna pohřbít pod nánosem kritik, zlovolností, neporozumění, vlastní omezenosti a školometství. Je sice pravda, že v Hamannově pozůstalosti se nacházelo nezměrné množství písemností, avšak nic, co by se dalo považovat za filosofické dílo v úzkém, profesním slova smyslu. Zda to byla neschopnost, jak usoudil Hegel v paralele s Jacobim (Hegel 1828, 280), nebo ostych či jakýkoli jiný osobnostní faktor, je právě tak málo důležité jako skutečnost, že Hamann stál mimo univerzitní intelektuální dění a mohl si dovolit dráždivou „neserióznost“, jíž se někdy říká originalita. ${ }^{12}$

Hamann nebyl systematicky píšíć filosof, sám se nejlépe cítil jako „metakritikus“; tuto přezdívku přijal nejen proto, aby dal najevo svůj vztah k „éře kritiky“ čili osvícenství, ale především kvůli objasnění svého poměru ke Kantovi. Z Hamannova kritického poměru $\mathrm{k}$ dobové filosofii vzešel nejeden podnět pro další, at' již současné nebo budoucí autory; patrně to ale nebyla síla, průraznost a důslednost jeho kritiky nejkritičtější epochy v kulturních dějinách evropské vzdělanosti, jako spíš fakt, že ze vší často chtěné a záměrné nesrozumitelnosti Hamannových textů vyčníval faktor kritické kritiky jako ten nejméně nesrozumitelný. Jestliže nemají být Hamannovy myšlenky pouze parafrázovány (a parafráze obecně dokládá prohru srozumitelnosti a přiměřené interpretovatelnosti a vítězství sektářské nápodoby), pak

\footnotetext{
${ }^{8}$ Srv. poznámku v dopise Fr. H. Jacobimu z 9. 4. 1786, kde Hamann říká: „Kant myslí jako každý systematik ... o svém systému jako římský katolík o své jediné církvi“ (Kant denke wie jeder Systematiker... von seinem System wie ein römisch Katholischer von seiner einzigen Kirche).

${ }^{9}$ Dopis Herderovi ze 7. 7. 1782.

${ }^{10}, \ldots$ ganze Vermögen zu denken beruht auf Sprache...“.

11 Tuto proslavenou přezdívku, která ale naznačovala, že luteránský mysticismus autora není nezbytné studovat, dal Hamannovi jeho vrstevník Friedrich Carl von Moser.

${ }^{12}$ Hegel na stejném místě mluví o celém „,věnci originálních individualit“, které se mohly rozvinout mimo centrum, na královecké periférii.
} 
z nich lze načerpat jen několik málo zdůvodnitelných a na rozumění založených popudů.

\section{Dva radikální osvícenci v příběhu antiosvícenství}

Metakritika ${ }^{13}$ rozumového purismu zapůsobila mezi těmito stimuly zřejmě nejsilněji; zejména z toho důvodu, že zprostředkovala nejprve německým, brzy však také evropským filosofickým kruhům spor o metodu filosofie I. Kanta. Jeho prvním krokem byl právě „,spor o metakritiku“, ne však ve fragmentární Hamannově verzi, ale v rozsáhlém dvousvazkovém pojednání J. G. Herdera (Herder 1799), v němž postavil proti Kantově metodě transcendentálního idealismu zvláštní spojení své empirické teorie poznání (tzv. spekulativního empirismu či senzualistického idealismu) s předkriticky založenou, čili z kantovských a pokantovských hledisek „dogmatickou“ metafyzikou. Jedná se nepochybně o velmi sporný spis, který lze kvůli interpretačním nedostatkům, jež z něj činí místy hádankovitou záležitost, zavrhnout tak, jak to učinili mnozí současní a pozdější vykladači (Jördens 1811; Goethe 1814; Hegel 1828; Unger 1905; Unger 1926, Dilthey 1936 ad.); zároveň s tím se však objevuje otázka, zda by při tak radikálním postoji nepřišel vniveč dosud ne zcela vyjasněný, ale přesto zřejmý význam Herderovy metakritiky pro těsně pokantovskou filosofii, pro novokantovství a pro velké systémy německého idealismu. Ostouzení, jemuž byl Herder osobně, argumentací vedenou ad hominem vystaven, vycházelo z řad Kantových stoupenců a obdivovatelů, původně jeho žáků; tón udal vydavatel Hamannovy metakritiky rozumového purismu F. T. Rink (Rink 1800), když v předmluvě spisu označil Herdera nelibými př́vlastky, z nichž se ujal a rozšíril termín ,plagiátor , jímž se připomínal fakt, že název Metakritika je přejímka od Hamanna. Hegel se víceméně korektně omezil na uvolněné povzdechnutí, že „s oprávněným despektem přijatá Metakritika je již dlouho po zásluze zapomenuta“ (Hegel 1828, 325), ${ }^{14}$ zatímco někteří z našich současníkủ, např. Heinrich Clairmont, už nedávají Herderovi šanci; dle něj svou neumělou kritikou $K \check{C} R$ ztratil své renomé filosofa nejen u svých stářníků, ale natrvalo (Clairmont 1988, 187). ${ }^{15}$

13 Termín „metakritika“ je již běžnou součástí filosofického slovníku, viz např. Heintel, E. (2017). Heslo Metakritika v Historickém slovníku filosofie, srv. Ritter, J./ Gründer. K./ Gabriel, G. (Hg.), Historisches Wörterbuch der Philosophie. Basel: Schwabe Verlag, 2487. DOI: 10.24894/HWPh.7965.0692. Dostupné online: $<$ https://www.schwabeonline.ch/schwabe-xaveropp/elibrary/start.xav?start=\%2F\%2F\%2A\%5 B\%40attr_id\%3D\%27hwph_productpage\%27\%5D >

14 „Man hat (Rink in Mancherlei zur Geschichte der metakritischen Invasion, 1800) diesen Aufsatz bereits ans Licht gezogen, um darin die Quelle nachzuweisen, aus welcher Herder seine mit großem Dünkel aufgetretene und mit gerechter Herabwürdigung aufgenommene, nun längst vergessene $\mathrm{Me}-$ takritik geschöpft habe“. Srv. též Hegel, G. W. F. (2001). Gesammelte Werke, Bd. 16: Schriften und Entwürfe II (1826 - 1831), Hamburg: Felix Meiner Verlag, 167.

15 „Herders Metakritik den philosophischen Ruf des Verfassers schon bei den Zeitgenossen dauerhaft ruiniert hat.“ 
Jak je možné myslet vztah řeči a rozumu - problém, který položil Hamann a dál v něm pokračoval Herder, oba s důrazem na to, že mluví o základní otázce kritické filosofie - tyto útoky př́liš nevyjasnily; ještě u Hegela, s jeho patrně nejvyšším nadhledem a s ambicemi, jež se týkaly přímo Kanta, bychom hledali vysvětlení tohoto vztahu marně. Pokud Hegel nějakou určitější představu měl, jak naznačuje často citovaná věta z jeho recenze prvního souborného vydání Hamannových spisů (Hegel 1828, 325), ${ }^{16}$ nikde ji nevykreslil, a to ne kvůli nevydařené Herderově metakritice (jež má podle Hegela s Hamanovým „duchaplným“ textem společné právě jen toto jméno), nýbrž patrně z respektu vůči Hamannovi a jeho odmítnutí formulovat pro tento vztah jakoukoli teorii (Majetschak 1988, 252).

Přes tyto rozpačité, nebo př́mo odmítavé reakce lze najít shodné body mezi oběma mysliteli a rovněž několik typických problémových okruhů, jež Herder převzal od Hamanna a rozvinul je bud' $v$ jeho původní intenci, nebo podle svého rozumění. Základním postojem byli oba tím, co se ve filosofických přehledech označuje výrazem ,empirikové'. Hamanna ovlivnil Luther a jeho prostřednictvím pavlovská teologie; obojí vlivy směřující $\mathrm{k}$ jistému snad naivnímu realismu, tkvícímu ve viře, že př́iroda tvoří spolu s díly vytvořenými lidským rozumem celek, který poznáváme jako demonstraci živého Boha. Současně jsou to vlivy, jež musely Hamanna a Kanta rozdělit, ne-li postavit do sporu. Vnesly do jejich intelektuálního vztahu neslučitelné momenty: jednak se začali vzájemně odsuzovat pro údajný mysticismus a jednak propukly zásadní neshody v pojetí náboženství. Kant soudil o Hamannovi jako mystikovi a blouznivci (Schwärmer), poněvadž tam, kde se prosazovalo ovlivnění Lutherem, viděl projevy myšlenek J. Böhma, a především E. Swedenborga; Kantův úsudek byl v tomto ohledu nesporně zbrklý, protože Hamann se seznámil se Swedenborgovými texty právě Kantovým prostřednictvím (kromě Kantova malého spisku o švédském autorovi si od Kanta půjčil jeho díla) a byl vůči němu radikálně odmítavý, zatímco u Böhmeho byly jeho znalosti výrazně fragmentární a spočívaly v oceňování myšlenky sjednocení protikladů (coincidentia oppositorum). Pokud se vezme v úvahu, že Hamann nepsal systematicky $\mathrm{z}$ důvodů, které uměl vysvětlit jako rys náležející k jeho smyslu pro skutečnost, nezbývá nic natolik ideálně typického, aby byl spojován s evropskou mystickou tradicí.

Stejně ovšem na opačné straně neskryl podežrení o Kantově mysticismu Hamann, i když nejspíš věděl, že k němu má jen chatrné argumenty; navíc se znali dost dobře, aby si byl jistý tím, že se Kanta nedotkne odborně i osobně ničím víc než touto nehorázností. Hamann sice mluvil o tom, že pokud se ve filosofii používají abstraktní

16 „Hamann stellt sich in die Mitte des Problems der Vernunft und trägt die Auflösung desselben vor; er faßt diese aber in der Gestalt der Sprache." (Hamann se postavil do centra problému rozumu a prednesl jeho řěseni; uchopil ho však v podobě řeči). 
(pro něj prázdné) pojmy, jež neoznačují nic názorného a pouze odtrhávají filosofii od živné půdy empirické skutečnosti a vynášejí ji vzhůru do výšin pojmového blouznění, pak může jít jen o mystické blouznění. Tento závěr je adekvátní Hamannovu nemálo naivnímu realismu, svědčí však o neúplném nebo zkresleném pochopení metody transcendentálního idealismu.

Hamann nechápal svůj znevažující odsudek ironicky ani jako pokus o humor, jak se občas předpokládá. Ironie a humor stojí mezi nástroji Hamannova stylu vysoko, a byt' nejsou často na místě, nezbytné ani žádoucí, a už vůbec ne plynule a hladce vyplývající z rytmu a způsobu Hamannova myšlení, ale spíš naopak, působí nuceně, strojeně, neuměle, spíś jako parodie na vtip a při snaze o porozumění textu také rušivě, přesto zůstává jedna oblast, kde se s nimi setkáme výjimečně. Touto oblastí jsou texty se vztahem k náboženství, nebo přímo k vlastní Hamannově religióznosti. Rozdílnosti mezi Kantem a Hamannem se mohly rozrůstat až k př́slovečným propastným rozměrům právě proto, že v jejich základech byl spor o náboženství. Hamann prodělal údajně osobní náboženskou krizi, která vyústila během jeho pobytu v Londýně v obrácení (Sievers 1969), jež spočívalo v rozhodnutí přijmout ,povolání křest’ana', tedy stát se křest’anským spisovatelem čili filosofem. ${ }^{17}$ Osobní náboženská pozice se stala zpočátku striktním, postupně ale stále uvolněnějším vodítkem Hamannova filosofování. Skeptický a svým způsobem dogmatický Kant neměl smysl pro náboženská pouta filosofie a nemohl akceptovat postoj, který neuznává základní určující diskurzivní hranice mezi ,vírou“ a ,poznáním‘ a jehož ústřední intence vede k izomorfii filosofie a náboženství, $\mathrm{k}$ nutné delegitimizaci myšlení a poznání, stejně jako $\mathrm{k}$ meto-

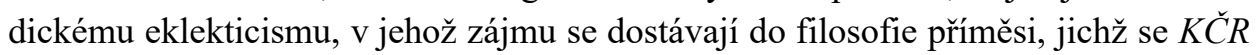
chtěla zbavit. Nepostřehl, že Hamannovo ovlivnění Humem je natolik zásadní, že mu nedovolí, aby se stal skutečně náboženským myslitelem, ale povede ho k myšlenkám a výrokům hodným d’áblova advokáta. Zároveň platí, že Kant neměl důvod zkoumat Hamannova nestálá psychická rozpoložení a již vůbec ne couvat znovu pod hranice toho, čeho v $K \check{C} R$ dosáhl.

Rozpad vztahu obou myslitelů, který začal Kantovou obavou o koherenci kritické filosofie a vyvrcholil smrští metakritických traktátů, je jakoby zmenšeným obrazem vnitřního rozkladu osvícenství, který začínal být nejvýraznějším rysem dění v evropské kultuře. Obojí se zakládalo na nepochopení druhé strany, obojímu byla

\footnotetext{
${ }^{17}$ Hamann přijel na původně služební cestu do Londýna v dubnu 1757 a zůstal zcela neplánovaně do června 1758. Zda byly jeho prožitky, soustřed'ující se do dnů kolem svátku Nanebevzetí panny Marie 1758, skutečně náboženským šokem vedoucím k metanoi, nervovým kolapsem v důsledku poněkud nevázaného života a nahromaděných dluhů, kulturním šokem plynoucím z porovnání Velké Británie se zaostalým německým soustátím, anebo, jak tvrdil Hegel, stavem psychické vyčerpanosti, bezradnosti, bláznivého poflakování bez jakéhokoli obsahu (Hegel 1828, 288 - 289, et passim) je otázka pro samostatnou studii.
} 
vlastní fixace každé ze zúčastněných stran na logiku a důslednost svého postoje, která vyústila ve vítězství tautologií a obrodě filosofií dějin, jež mohly znovu svobodně předpovídat budoucnost lidských společností a stanovovat zákonitosti dějin. Hamann a Kant následovali proces, který v jiné souvislosti označil americký autor Leonard P. Wessell jako „kognitivní krizi osvícenství“ (Wessell 1979 235). ${ }^{18}$ Hamannův myšlenkový svět se zakládal na prožitku obrácení, jehož optikou posuzoval Kantovu metodu, která vyloučila z poznání prírody a dějin ideu Boha. V Hamannově teorii poznání, opřené o náboženství a o teorii jazyka, bylo naopak vše, co se děje v př́rodě a v dějinách, znázorněním Boží vůle. Náboženský symbolismus se nedá sloučit $\mathrm{s}$ Kantovým kriticismem ani přesto, že východiskem obou byl kritický poměr k rozumu. Hamannova skepse vǔči rozumu byla dokonce radikálnější než Kantova, avšak ve spojení se senzualistickou teorií poznání se z ní stal pouze předpoklad Hamannovy náboženské filosofie. V ní pak stojí zcela klasicky víra nad rozumem, poněvadž je poznáním, v němž každá zkušenost přináší (různě transformovaný) poznatek o transcendentním Bohu. Lepší př́íklad kognitivní krize na rozhraní Kantovy Kritiky a Hamannovy Metakritiky Kantovy koncepce kritiky čistého rozumu asi nenajdeme.

\section{Řečový monismus Metakritiky}

Původní účel metakritiky spočíval ve snaze přimět Kanta, aby do koncepce $K \check{C} R$ zapracoval filosofii jazyka, založenou na principu priority řeči před rozumem, jak jej vyjadřuje Hamannovo heslo, ,rozum je řeč“. ${ }^{19}$ Požadavek na zahrnutí filosofie jazyka do metody transcendentálního idealismu byl racionální a oprávněný; at' už byly Kantovy pohnutky jakékoli, odsunutí dílčího výkladu vztahu mezi rozumem a řeči až do pozdní Antropologie v pragmatickém ohledu $u^{20}$ (Kant 1798), a tím způsobené odloučení od všech tří kritik, nebylo št’astné rozhodnutí. Podle charakteru dnešních diskusí o další recepci Kantovy nauky a o jejím budoucím vlivu na prostředí filosofie nesmazatelně poznamenané obratem k jazyku lze soudit, že absence filosofie jazyka bude Kantovu pozici objektivně oslabovat. V době invaze metakritiky do $K \check{C} R$ tento prvek ještě váhu neměl, zato se vedly diskuse mezi stoupenci tradičního racionalistického pojetí, dle nějž struktury myšlení determinují jazykové struktury, a obhájci opačného hlediska, že jsou to právě kategorie myšlení, které jsou determinovány původními jazykovými kategoriemi. Protože Hamann v metakritice napsal, že veškerá mohutnost myšlení se zakládá na řeči, a proto je řeč zároveň středobodem nedorozumění rozumu

18 "Lessing's thinking was caught on the horns on a 'cognitive crisis' in Enlightenment thought."

19 "Vernunft ist Sprache", v dopise J. G. Herderovi ze dne 6. 8. 1784.

${ }^{20}$ Anthropologie in pragmatischer Hinsicht, poslední dílo, které Kant sám vydal, vznikalo v letech 1796 - 1797. Je to spis se složitým osudem a neméně složitým obsahem; zde ale lze pouze odkázat na to, že se v něm objevuje nijak zvlášt' objevná teorie jazyka jako prostředku reprezentace. 
se sebou samým, byly mu přisouzeny sympatie $\mathrm{k}$ druhé teorii směřující $\mathrm{k}$ řečového relativismu.

Zjevně neoprávněně, jak je patrné z dalších Hamannových tezí a rovněž z Herderova způsobu navázání na Hamannovy úvahy, jímž koncepci jazyka dynamizoval převedením na oblast vzdělávání. ${ }^{21}$ Elisabeth Leissová, znalkyně Hamannovy jazykové teorie, tvrdí, že na Metakritice se výrazně podepsala Hamannova inklinace k tzv. všeobecným gramatikům, zejména $\mathrm{k}$ britskému osvícenci Jamesi Harrisovi (1708 - 1780), autorovi dobově populárního díla Hermes, or, A philosophical enquiry concerning language and universal grammar. V jeho třetím vydání ze srpna 1771 Hamann našel prvky náležející k metakritice čistého rozumu, jak radostně sdělil Jacobimu v dopise z 2. 6 . 1785 (Liess 1991, 264). ${ }^{22}$ Protože to bylo již rok od náčrtu Metakritiky rozumového purismu v dopise Herderovi, chápal Hamann svůj výrok o identitě rozumu a řeči odlišně, než jak by vyžadovala teze jazykového relativismu. Hlavní odlišnost spočívá v tom, že jeho výrok se netýká specifických struktur jednotlivých jazyků, ale komplexní architektoniky pojmů; když Hamann říká, že ,,̌reč je dělohou našich pojmů“ ${ }^{23}$ nemyslí tím proměnlivost intenzionálního a extenzionálního významu pojmů $\mathrm{v}$ jednotlivých jazycích, ani její vliv na tvorbu různých kategorizací pojmově vyjádřených představ o světě. Naopak, místo pojmových kontrapozicí se přidržuje principu coincidentia oppositorum a bere protikladné pojmy jako zcela přirozené koreláty, tzn. vždy souvztažně. Liessová zde nachází základy principu, který, je-li vyjádřen jazykem dnešní lingvistiky, znamená, že „antonyma se v archilexému převádějí na vyšší společný jmenovatel, a právě antonyma, přesně vzato, znázorňují velmi blízká synonyma“ (Liess 1991, 264). ${ }^{24}$ Nejedná se o nic jiného, než o princip organizace obecného lexikonu, tzn. Hamannův zájem se v jeho filosofii jazyka soustředí na architektoniku, kterou by sdílely všechny jednotlivé jazyky.

Nejen v tomto závěru Hamannovy filosofie jazyka, ale hlavně v jejích předpokladech zaznívá něco, co patrně bylo zřejmé Kantovi a spolurozhodovalo o jeho odmítnutí Hamannova nátlaku na úpravu $K \check{C} R$. Myšlenka architektoniky společné všem jazykům předpokládá všem jazykům společná pravidla, která musejí vycházet z jed-

${ }^{21} \mathrm{~V}$ téže návaznosti pokračoval v rozvíjení hamannovsko-herderovské teze Wilhelm von Humboldt (1795), bez nějž by se asi neměl problém filosofie jazyka $v$ metakritice kantovského kriticismu vůbec otevírat. Z trojice Hamann - Herder - Humboldt to byl právě on, kdo přinesl rozhodující argumenty ve prospěch myšlenky, že jednotlivé jazyky jsou historickou podmínkou myšlení. Vynechávám ho zde z prostorových důvodů a s vědomím, že tím zakládám neúplnost tohoto textu. Pro doplnění odkazuji alespoň na jeden $z$ dodnes nepřekonaných výkladů této koncepce u Fritze Mauthnera (1912).

${ }^{22}$ Er finde hier ,lauter Elemente zu einer Metakritik der reinen Vernunft“.

${ }^{23}$ Řeč jako „Gebährmutter unserer Begriffe“, v dopise Jacobimu z 22. 1. 1785.

${ }^{24}, \ldots$ daß Antonyme im Archilexem auf einem gemeinsamen Nenner aufgehoben sind und daß gerade Antonyme genau genommen sehr nahe Synonyme darstellen.“ 
noho prvotního a určujícího pravidla; uvnitř všech jazyků vládne tudíž jakási neviditelná, jemně působící, avšak nezdolná metafyzika - skrytá metafyzika jazyka, která, bude-li odhalena, stane se klíčem ke všemu vědění a všem vědám. Pro Hamanna a Herdera nelze „metafyziku jazyka“ odkrýt mimo zkušenost, jež následně limituje všechny vědy, pro něž je taková metafyzika svým způsobem apriori. Tím se potvrzuje platnost empirismu jako jednoho z nosných prvků metakritiky. $Z$ dominantního vlivu zkušenosti se rovněž odvozuje, že mezi logickými a gramatickými strukturami sice platí vztah homologie, avšak řečové struktury nemohou být nikdy odvozeny z logických struktur: relace říká „rozum je řeč“, nelze ji obrátit na „řeč je rozum“ - podle Hamanna je pojem užitý predikativně vždy širší, takže mezi rozumem a jazykem platí vztah inkluze. Znovu Liessová: „Kognitivní mohutnost řeči v sobě zahrnuje všechny další dílčí kognitivní mohutnosti, např. mohutnost rozumu“ (Liess 1991, 265). ${ }^{25}$

Tento vztah ale, zdá se, ukazuje jiným směrem než první zásada skryté metafyziky jazyka, podle níž je tato metafyzika zakotvena ve zkušenosti; jestliže představuje současně s tím apriori všeho vědění a poznání, vyvstává zde rozpor. Hamann ho nezastírá, spiśs prohlubuje: řeč podle něj není pouze nástroj používaný $\mathrm{k}$ vzájemné výměně myšlenek, názorů, postojů nebo citů, nýbrž představuje první předpoklad dobývání veškerého poznání. Všechno bohatství vědění a poznání, jímž lidé disponují, se zakládá na „výměně slov“ (Wortwechsel, míněno patrně ironicky jako analogie ekonomické „směny zboži“). Ačkoli zní tato teze jako další z Hamanových a Herderových redukcionismů, vyznívá v jeho opak: pokud je totiž „směna slov“, tj. výměna myšlenek předpoklad pro vytváření bohatství lidských poznatků, musí předcházet jakoukoli činnost, jež k němu vede a s níž lze mít zkušenost. To, co předchází zkušenost, bývá označováno jako apriorni; ; řeč je tudíž dle Hamanna apriori všeho poznání.

Jedno ze základních pravidel poznání vyžaduje, aby teorie, z níž ta která cesta a forma poznání vychází, byla bezrozporná. Hamannova teorie tomuto požadavku nevyhovuje, protože klade na svůj počátek současně apriori a aposteriori (v obecném smyslu předzkušenostní apriori a zkušenost); tím se dostává do rozporu sama se sebou. Asi by se nic nezískalo spekulací, zda si Hamann uvědomoval situaci, v níž se ocitl a vědomě ji ignoroval, nebo ošemetnost svých konkluzí nepostřehl; takové úvahy se vznáší na obláčcích psychologismů, zpravidla spojených s údajnou schopností hermeneutiky „,vcítit se“ do autora textu. Než tato nikdy ničím nedoložená šamanská empatie víc pomůže pohled na způsob Hamannova písemného vyjadřování, na jeho tolikrát kritizovaný, nebo naopak vzývaný styl špatně dávkované nesrozumitelnosti. Typické je pro něj seřazování explozí jednotlivých úvah a myšlenek, tak jak se odehrály, bez doplnění jejich vzájemné provázanosti (pokud vůbec jakou měly) a celkové, tzn.

25 „Das kognitive Vermögen der Sprache umfaßt alle anderen kognitiven Teilvermögen, wie z. B. das der Vernunft.“ 
rovněž logické souvislosti. Hamann nebyl systematik, nechtěl jím být a spíš si zakládal na vytváření nejrůznějších souostroví z ostrůvků svých myšlenek, mezi nimiž si musí najít cestu sám čtenár. Problém, o který šlo, se týkal jednoty názoru a pojmu ve slově, v řeči; byl první z německých filosofů 18. století, který promýšlel vztah řeči a myšlení a formuloval tezi, podle níž je nauka o rozumu bez teorie řeči vždy neúplná, a tudíž v důsledku nemožná. $K \check{C} R$ je možná jako kritika řeči, pokud nepředpokládáme rovnou, že obě mohou být kritikami jen tehdy, jsou-li totožné. S takto vyhrocenými větami, které jsou v jeho textech roztroušené jako hraniční kameny v krajině, není nezbytné bezvýhradně souhlasit, ale také jim nelze upř́t jistou nosnost, jež se mohla projevit při hledání východisek z obtíží, do nichž se dostala záhy po Kantovi celá aprioristická teorie poznání - mohla, ale $\mathrm{v}$ zásadě neprojevila, protože pro dobovou německou filosofii nebyl Hamann (zčásti také kvůli spjatosti s Herderovou koncepcí metakritiky) dostatečně renomovaný, aby byl brán v potaz.

Herderovo pojetí metakritiky sdílí analogické zásady s Hamannovým, s tím rozdílem, že tam, kde Hamann předjímá s intuitivní jistotou souvislosti a vztahy, aniž by je dál rozpracoval, sleduje Herder pečlivěji Kantovy argumentační kroky a vytvář́i své vlastní ,anti-analytiky“. Tam, kde Hamann konstatoval vztah mezi myšlením a řečí, argumentoval Herder proti transcendentálnímu idealismu z téže pozice, ale už spojené se srozumitelným výkladem. Jeho osu tvoří teze, podle níž je lidská schopnost poznání a usuzování specificky determinovaná jazykovou praxí. Řeč, slova nás učí myslet a myslet můžeme tehdy, dokážeme-li myšlenky formulovat jazykově; tím se jazyk vymaňuje z role zrcadla, jehož úkolem je odrážet již poznanou skutečnost, a přesouvá se do okruhu nástrojů sloužících samotnému získávání a rozvíjení poznání. Mezi nimi měla v tradici „filosofie vědomí“ (Bewusstseinsphilosophie) výsadní postavení percepce, chápaná jako přirozená danost př́íslušející člověku. Herder ji neměl v úmyslu zpochybnit, pouze ukázal na určující vztah, v němž podle jeho přesvědčení působí: proti sobě už nemá umělý systém znaků vyznačujících obsahy našeho poznání, ale vztahuje se sama k sobě, ke svému svébytnému niternému momentu, jehož prostřednictvím znázorňuje samu sebe formou slov a řeči.

Herder byl nedůsledný a mluvil i nadále o vynálezu (Erfindung) jazyka, i když je zřejmé, že neuvažoval o vzniku, rozvinutí či vytvoření řeči, ale měl na mysli zásadní určení (Bestimmtheit) lidské existence jakožto rozumové existence: určení jazyka a jazykem (Cassirer 1996, 104). ${ }^{26}$ Bez ohledu na to způsobila Herderova koncepce „rozumu jazyka“ (Cassirer 1996, 96) další trhlinu v myšlení Bewusstseinsphilosophie,

26 „Proto pro Herdera jazyk - i když neustále mluví o jeho ,vynalezení - nikdy není něčím pouze vytvořeným, nýbrž je něčím vnitřně a nutně vzniklým. Je faktorem v samotné syntetické výstavbě vědomí, díky němuž se svět smyslových počitků utvárí nejprve jako svět názoru; není tudíž žádnou věcí, která je vytvořena, nýbrž je druhem a určeností duchovního plození a tvoření.“ 
která se již nedala zahladit; subjektivita, individualita, formální rámec vzniku individuálního Já, na jehož tvorbě se podílela celá novověká filosofie, se přenášejí ze sféry leibnizovské apercepce do jazykové oblasti. To není žádný linguistic turn 18. století: nic takového se neodehrálo, Herder nestál na prahu takového obratu a sdílel intence myšlení sahajícího od Bacona a Leibnize přes Harrise a Hamanna, jehož obsahem bylo zjištění pozice a funkce jazyka při plném uvědomění lidské subjektivity.

Pokud lze v těchto víceméně kulturně-dějinných rozsáhlých procesech, které se nejvíc týkaly změny v typu racionality, vrcholící v době mezi 1750 - 1850, zobecnit př́nos metakritiky rozumového purismu, pak snad tím, že ji vykreslíme jako velmi důležitou součást metodických sporů o dominanci konkrétního předmětu filosofických zkoumání. Mezi jejich účastníky ale nebyl nikdo, kdo by předvídal či alespoň tušil, že právě zakládaná dominance filosofie jazyka vyústí ve zkáze filosofie, omezené na hledání toho, co je či není na pozadí jazyka, ani nikdo další, kdo by se zamyslel nad faktickým postavením individua vmáčknutého do lisovací formy abstraktní teorie člověka. Stejně jako dnes, ani tehdy se filosofie neuměla dívat sama sobě přes rameno.

\section{Závěr}

„Výměna slov“ je př́lišs zjednodušené označení faktoru, jehož analytické začlenění do hlavního proudu kritické filosofie druhé poloviny 18. století postrádal Hamann tak silně, že z něj udělal drásavý hrot protikantovského výpadu označeného termínem metakritika. Skrývalo se za ním mnohem víc, než mohli současníci odhadovat. Stála za ním Hamannova netrpělivost, ve výkladech dějin filosofie mnohdy podceňovaný osobnostní rys. Hamann znal $K \breve{C} R$ velmi dobře, četl a recenzoval ji jako vůbec první čtenář. Nepochybně také pochopil, co se začíná s tímto spisem dít v evropské filosofické tradici; filosofie po $K \check{C} R$ nebude už nikdy tím, zač ji chtěla mít nehnutá, v sobě samé spočívající, zpravidla teologická metafyzika. Protože okamžitě odhalil největší slabinu transcendentálního idealismu, zásadní opomenutí vztahu myšlení a řeči, je velmi pravděpodobné, že ji pochopil nejdůkladněji ze všech čtenářù v kantovské a těsně pokantovské generaci německých intelektuálů. Zároveň jako myslitel odkojený Humovou skepsí nemohl nemít pochybnosti o ,čistotě“ a jednoznačné síle rozumových výkonů, z kterých se nedají odstranit mimorozumové prvky: zvyky, pověry a především to, co v člověku zůstává z přírody, vášně, imprese, instinkty a instinktivní reakce, jejichž rychlost předchází všechna rozumová uvážení, o volních rozhodnutích nemluvě. Kdyby se na místo této humovské součásti celkové konstituce člověka dosadilo Hamannovo pojetí řeči, vysvětlila by se další specifická souvislost metakritiky: řeč působí, a její působení má účinek analogický vlivům prírody v člověku. Zprostředkovává mezi smyslovými počitky, zkušenostmi, nažrením, sledem lidských představ 
a samotným chodem př́rody a činí tak jejich nápodobou. Do okamžiku této prostředkující nápodoby umístil Hamann „sílu“ či „moc“ řeči, která je lidskému vědění dosud nedostupná a skrývá se v „hlubinách řeči“, o kterých „,učenci nevědí nic“. Mimetická teorie řeči, kdy je řeč prŕrody napodobovaným předobrazem řeči člověka, je tak u Hamanna důstojnou kamufláži pochybnosti o rozumu, který se podřizuje jakoby instinktivní moci řeči.

Spojí-li se oba tyto faktory - dokonalé pochopení $K \check{C} R$ a okamžité rozeznání její největší slabiny, k němuž Hamannovi dopomohla Humova skepse -, vyhližźi Hamannova reakce na Kanta skutečně jen jako neadekvátní projev netrpělivosti, který žádoucí kritiku Kantovy kritiky a s ní celý další rozvoj tohoto typu kritického myšlení neurychlil ani v nejmenším. $\mathrm{V}$ jejím důsledku se přenesl ústřední a $\mathrm{v}$ zásadě jediný problém metakritiky na Herdera, který disponoval historicky značně významnou, neli epochální historicko-filologickou teorií jazyka, publikovanou 1772 po názvem $A b$ handlung über den Ursprung der Sprache, avšak ve srovnání s Hamannem mnohem nižší úrovní porozumění. Kantově kritické fillosofie, zejména co do její tendence a celkové orientace. Herderův text o rozumu a zkušenosti, díky němuž je dnes termín metakritika ve filosofii běžný, není zdařilé dílo.

Herder prokázal, že řeč je neredukovatelná součást lidské (praktické) činnosti, aniž by bylo nutné prokazovat specifickou rozdílnost této praxe; zapojil řeč do komplexní situace člověka ve světě a v ní zdůvodnil základy antiredukcionistické teorie jazyka; vyložil vliv nejazykových vztahů, vazeb a souvislostí vznikajících mezi lidmi, na řeč; dovedl osvícenství k jednomu z mála závěrů, když ukázal, že jazykové dorozumění může existovat pouze $\mathrm{v}$ závislosti na rozvoji myšlení, tzn., že úroveň myšlení (nezbytně spojená s úrovní vzdělanosti) určuje možnosti jazykového dorozumění. Nic z toho nelze Herderovi upř́t, ovšem nic z toho neodvodil Herder z metakritiky rozumového purismu. Další projev konstitutivní ironie v dějinách filosofie?

\section{Literatúra}

BAYER, O. (1987): Die Geschichten der Vernunft sind die Kritik ihrer Reinheit. In: Gajek, B. (Hg.): Hamann - Kant - Herder. Acta d. 4. Internationalen Hamann-Kolloquiums im Herder Inst. zu Marburg/Lahn. Frankfurt [u. a.]: Lang, $9-87$.

BAYER, O. (1995): Johann Georg Hamann - radikaler Aufklärer als Metakritiker. In: Kreimendahl, L. (Hg.): Aufklärung und Skepsis. Festschrift für Günter Gawlick. Stuttgart - Bad Canstatt: Frommann-holzboog Verlag, 9 - 21.

BAYER, O. (1998): Johann Georg Hamann: ,, der hellste Kopf seiner Zeit“. Tübingen: Attempto.

BAYER, O. (2002): Vernunft ist Sprache: Hamanns Metakritik Kants. Stuttgart - Bad Canstatt: Frommann-holzboog Verlag.

BERLIN, I. (1995): Der Magus in Norden: J. G. Hamann und der Ursprung des modernen Irrationalismus. Berlin: Berlin Verlag. 
BROSE, Th. (2006): Johann Georg Hamann und David Hume: Metaphysikkritik und Glaube im Spannungsfeld der Aufklärung, 2 Band. Frankfurt am Main: Lang.

CLAIRMONT, H. (1988): >Metaphysik ist Metaphysik Jamme, Ch. - Kurz, G. (Hg.): Idealismus und Aufklärung. Kontinuität und Kritik der Aufklärung in Philosophie und Poesie um 1800. Stuttgart: Klett-Cotta, 179 - 200, cit. 187 an.

CASSIRER, E. (1996): Filosofie symbolických forem I, Jazyk. Praha: Oikoymenh.

DILTHEY, W. (1936): Johann Georg Hamann. In: týž, Gesammelte Schriften. Band XI: Vom Aufgang des geschichtlichen Bewußtseins. Jugendaufsätze und Erinnerungen. Leipzig - Berlin: Verlag B. G. Teubner, $1-39$.

GAIER, U. (1988): Herders Sprachphilosophie und Erkenntniskritik. Stuttgart - Bad Cannstatt: Frommann-holzboog Verlag.

GOETHE, J. W. von (1811 - 1814): Aus meinem Leben. Dichtung und Wahrheit, III. Bd. Tübingen: Klett-Cotta.

HABERMAS, J. (1983): Die Verschlingung von Mythos und Aufklärung. Bemerkungen zur Dialektik der Aufklärung - nach einer erneuten Lektüre. In: Bohrer, K.-H. (Hg.): Mythos und Mo derne. Begriff und Bild einer Rekonstruktion. Frankfurt am Main: Suhrkamp, 405 - 431, 418.

HAMANN, J. G. (1784): Metakritik über den Purismum der Vernunft. Text der Metakritik in der Fassung ihrer Mitteilung an Johann Gottfried Herder am 15. September 1784. In: týž, Briefwechsel. Fünfter Band. 1783 - 1785. Hg. v. Arthur Henkel. Frankfurt 1965, 210 - 216.

HARRIS, J. (1771): Hermes, or, A philosophical Inquiry Concerning universal grammar. London: J. Nourse and P. Vaillant.

HAYM, R. (1877/1885): Herder nach seinem Leben und seinen Werken, 2 Band. Berlin: Weidmannsche Buchhandlung / Gärtner Verlag.

HEGEL, G. W. Fr. (1828): Hamanns Schriften. In: Moldenhauer, E. - Michel, K. M. (Hrsg.): Werke. Band 11, Berliner Schriften 1818 - 1831. Frankfurt: Suhrkamp 1986, 275 - 352.

HEINZ, M. (1994): Sensualistischer Idealismus. Untersuchungen zur Erkenntnistheorie und Metaphysik des jungen Herder (1763 - 1778). Hamburg: Felix Meiner Verlag.

HERDER, J. G. (1763): Versuch über das Sein. In: Gaier, U. (Hg.). Frühe Schriften $1764-1772$ Frankfurt: Deutscher Klassikerverlag 1985, 9 - 21. In: Herder, J. G. Werke. Zehn in elf Bänden, hrsg. Arnold, G. / Bollacher, M., Frankfurt: Deutscher Klassikerverlag 1984 - 2000, sv. I.

HERDER, J. G. (1799): Verstand und Erfahrung. Eine Metakritik zur Kritik der reinen Vernunft, erster Theil, Leipzig: Hartknoch; zweiter Theil, Leipzig: Hartknoch. In: Suphan, B. (Hg.): Sämtliche Werke, 21. Band. Berlin: Weidmannsche Buchhandlung 1881.

HORKHEIMER, M. - ADORNO, Th. W. (1969): Dialektik der Aufklärung. Philosophische Fragmente (1944). Frankfurt am Main: Fischer (český překl. Hauser, M., Váňa, M.: Dialektika osvicenství. Praha: Oikoymenh 2009).

HORYNA, B. (2005): Dějiny rané romantiky. Fichte - Schlegel - Novalis. Praha: Vyšehrad.

HORYNA, B. (2006): Filosofie skepse. Olomouc: Nakl. Olomouc.

HUMBOLDT, W. von (1795): Über Denken und Sprechen. In: Leitzmann, A. (ed.): Gesammelte Schriften, Akademieausgabe, Bd. VII. Berlin: de Gruyter, 581 - 583.

JÖRDENS, K. H. (1811): Lexikon deutscher Dichter und Prosaisten, Bd. VI. Leipzig: Weidmann.

KANT, I. (1798): Anthropologie in pragmatischer Hinsicht abgefaßt von Immanuel Kant. Königsberg: Friedrich Nicolovius.

KIESEWETTER, J. G. C. Ch. (1799): Prüfung der Herderschen Metakritik der reinen Vernunft in welcher zugleich mehrere schwierige Stellen in der Kritik der reinen Vernuft erläutert werden. Berlin: C. Quien.

LIESS, E. (1991): „Die Vernunft ist ein Wetterhahn“ Johann Georg Hamanns Sprachtheorie und die Dialektik der Aufklärung. Zeitschrift für germanistische Linguistik, 19 (3), 259 - 273. DOI https://doi.org/10.1515/zfgl.1991.19.3.259 
MAJETSCHAK, S. (1988): Vom Sprechen und Hören des Wortes. In: Majetschak, S. (Hrsg.): Johann Georg Hamann, Vom Magus im Norden und der Verwegenheit des Geistes. Ein HamannBrevier. München: Deutscher Taschenbuch Verlag, 231 - 257.

MAJETSCHAK, S. (1989): Metakritik und Sprache. Zu Johann Georg Hamanns Kant-Verständnis und seinen metakritischen Implikationen. In: Société Française de Philosophie, Bulletin, 80 (4), 447.

MAUTHNER, F. (1912): Zur Sprachwissenschaft. Beiträge zu einer Kritik der Sprache. Zweiter Band. Stuttgart: Cotta.

MICHALSKY, O. (1883): Kant's Kritik der reinen Vernunft und Herder's Metakritik. Breslau: Buchdr. Schreiber \& Stummer.

PIETSCH, L.-H. (2010): Topik der Kritik: Die Auseinandersetzung um die Kantische Philosophie (1781-1788) und ihre Metaphern. Berlin - New York: Walter de Gruyter.

RINK, F. T. (1800): Mancherlay zu Geschichte der metacritischen Invasion. Nebst einem Fragment einer ältern Metacritik von Johann George Hamann, genannt Magus in Norden, und einigen Aufsätzen, die Kantische Philosophie betreffend. Königsberg: Friedrich Nicolovius.

SCHLEGEL, F. (1813): Deutsches Museum, III. Band, Erstes Heft. Wien: Camesina, 33 - 37.

SIEVERS, H. (1969): Johann Georg Hamanns Bekehrung. Ein Versuch, sie zu verstehen. Zürich Stuttgart: Zwingli Vlg.

SŤAHEL, R. (2019): Pojem krízy v environmentálnom myslení. Bratislava, Iris.

TITTEL, G. A. (1787): Kantische Denkformen oder Kategorien. Frankfurt am Main: Gebhardische Buchhandlung.

UNGER, R. (1905): Hamanns Sprachtheorie im Zusammenhange seines Denkens. Grundlegung zu einer Würdigung der geistesgeschichtlichen Stellung des Magus im Norden. München: C. H. Beck / C. H. Beck'sche Verlagsbuchhandlung.

UNGER, R. (1911): Hamann und die Aufklärung. Studien zur Vorgeschichte des romantischen Geistes im 18. Jahrhundert. Jena, E. Diederichs.

WESSEL, L. P. (1977): G. E. Lessing's Theology: A Reinterpretation: A Study in the Problematic Nature of the Enlightenment. The Hague: De Gruyter Mouton.

Tato studie vznikla s podporou grantu VEGA č. 1/0291/18 Historicko-filozofická analýza environmentálneho myslenia, skúmanie jeho vplyvov na etické, právne a politické myslenie a jeho spoločenská odozva.

Břetislav Horyna

Filozofický ústav SAV

Klemensova 19

81364 Bratislava

Slovenská republika

e-mail: filohory@savba.sk

ORCID ID: https://orcid.org/0000-0002-6610-246X 